\title{
Using Digital 3D Scanning to Create "Artifictions" of the Passenger Pigeon and Harelip Sucker, Two Extinct Species in Eastern North America: The Future Examines the Past
}

\author{
Bruce L. Manzano ${ }^{1 *}$, Bernard K. Means ${ }^{2}$, Christopher T. Begley ${ }^{3}$, and Mariana Zechini ${ }^{4}$
}

Author addresses: ${ }^{1}$ University of Kentucky, Program for Archaeological Research, 1020A Export Street, Lexington, Kentucky 40506-9854, USA, ${ }^{2}$ Virginia Commonwealth University, Department of Anthropology, Lafayette Hall Room 310,312 North Shafer Street, Richmond, Virginia 23284-2021, USA. ${ }^{3}$ Transylvania University, Department of Anthropology, Hazelrigg Hall Room 105, 300 North Broadway, Lexington, Kentucky 40508-1797, USA. ${ }^{4}$ University of West Florida, Division of Anthropology and Archaeology, Building 13, 11000 University Parkway, Pensacola, Florida 32514, USA.

*Corresponding Author: blmanz2@uky.edu

Received: March 16, 2015

Published: December 18, 2015

Volume: 6(2):232-241

(C) 2015 Society of Ethnobiology

\begin{abstract}
The Virtual Curation Laboratory at Virginia Commonwealth University created 3D representations of digital morphological models, termed "artifictions," of several bone elements from two extinct animals, the passenger pigeon (Ectopistes migratorius Linnaeus Columbidae) and the harelip sucker (Moxostoma lacerum Jordan and Brayton Catostomidae). Procuring recent comparative reference skeletons these species is extremely difficult. The creation of artifictions, $3 D$ printed replicas of skeletal remains, aims to help researchers become familiar with the bones of harelip sucker and passenger pigeon to facilitate morphological identification of remains of these species within archaeological assemblages. Here, we discuss the two species, the techniques used to create digital topological models of individual skeletal elements, and the obstacles encountered regarding 3D printed artifictions in zooarchaeology.
\end{abstract}

Keywords: Skeletal elements, 3D printing, Extinct species, Passenger Pigeon, Harelip Sucker

\section{Introduction}

Zooarchaeology increasingly employs advances in computer digital technology that expand its application not only in archaeology but also in wildlife management, conservation biology, and law enforcement (Sims et al. 2011). This expansion reflects the wide diversity of zooarchaeological techniques as well as their relevant applicability beyond archaeology (see Lyman 1996, 2012; Wolverton and Lyman 2012). Through applied zooarchaeology, researchers are able to investigate the anthropogenic and natural processes that contributed to past environmental conditions in order to offer insight into appropriate long-term conservation and management challenges present in many regions of the world today. A key goal in applied zooarchaeology is to conduct research that increases understanding of the factors leading to animal extinctions and shifts in species distribution and abundance over time (Lyman 1996:119).

This paper contributes to this goal by creating three-dimensional (3D) replications, or "artifictions"1 of skeletal parts of the passenger pigeon (Ectopistes migratorius Linnaeus Columbidae) and harelip sucker (Moxostoma lacerum Jordan and Brayton Catostomidae), two extinct species with remains that are found in North American archaeological and paleontological assemblages. In the 1800s, the passenger pigeon was the most abundant bird species on Earth, with a range across a large part of North America (Figures 1a and 1b), but, largely from human overhunting, it became extinct by the early $20^{\text {th }}$ Century (Greenberg 2014:1). ${ }^{2}$ September 1, 2014 marked the centenary of extinction for the passenger pigeon with the death of Martha, the last living specimen who died in captivity at the Cincinnati Zoo (Figure 1a). Humans utilized the passenger pigeon as a food source that extended deep into antiquity up to the late 19th century (Greenberg 2014), and archaeologists have regularly identified it in faunal assemblages (e.g., Jackson 2005, Neumann 1985, Scott 2008).

In contrast, remains of the harelip sucker (Figure 2a) are seldom identified from archaeological faunas. 


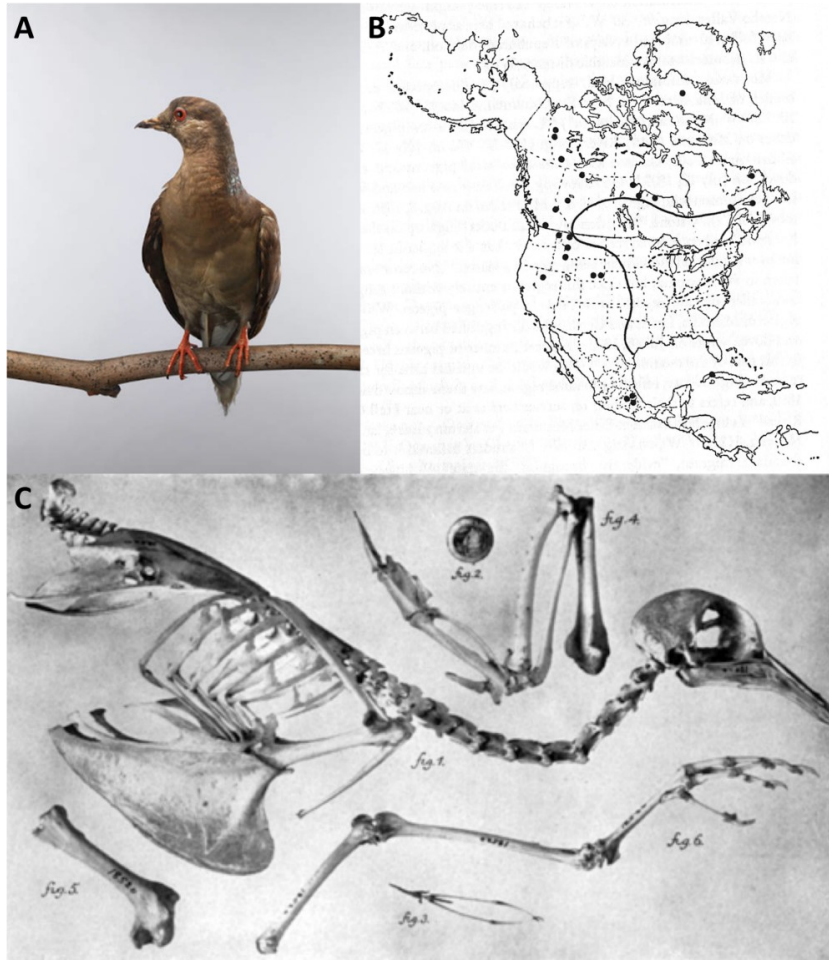

Figure 1. A) Martha, the Last Passenger Pigeon, (reproduced with permission from the Smithsonian National Museum of Natural History, USNM \#223979), B) Distribution Map for the Passenger Pigeon (1534-1894). Solid line encloses area of normal distribution. Dotted line encloses principal nesting area. Solid circles represent causal or accidental occurrences (reproduced with permission from the University of Oklahoma Press; Schorger 1955:257, Figure 22), C) Photograph of a male passenger pigeon skeleton housed in the Smithsonian Institution (Specimen \#18520) (reproduced with permission from The Auk; Shufeldt 1914:358).

This species was once widespread throughout the east central region of the United States (Jenkins 1980:407), which may suggest it has been under-identified in archaeological assemblages (Figure 2c). Indeed, based on their identification of 113 harelip sucker remains at Eastman Rockshelter (Tennessee), Manzano and Dickinson (1991) urged researchers to become aware of the potential occurrence of this fish in faunas, but a lack of comparative specimens inhibited this effort.

Remains of extinct animal species are particularly difficult for zooarchaeologists to identify because researchers can only access comparative specimens obtained prior to extinction, partial specimens from archaeological and paleontological assemblages, or photographs and illustrations of key elements. To address this problem, this paper describes the development of a 3D scanning and printing process (see McCuistion 2013; Means 2014, 2015a, b; Means et al. 2013a, b; Zechini 2014a, b, c, d) to produce replicas that can aid in identifying the skeletal elements of these two extinct species (see also McCuistion 2013; Means 2014, 2015a, b; Means et al. 2013a, b; Zechini 2014a, b, c, d). This effort complements the increasing digital technological developments in archaeology discussed at the $11^{\text {th }}$ International Council for Archaeozology (ICAZ): see papers in McKechnie and Kansa (2011), the Proceedings of the 2013 Digital Heritage International Congress (e.g., Heerlien et al. 2013, Richter et al. 2013), as well as Ahmed et al. (2014) and Chapman et al. (2013). The Virtual Zooarchaeology of the Arctic Project (Betts et al. 2011) utilized 3D scans to improve specimen identifications in the lab and/or field (Betts et al. 2011), and has also established 3D scanning protocols that enable point-to-point morphometric measurements and size-based species identifications that are useful in studies of environmental change (Klippel and Parmalee 1982). Use of comparative skeletal specimens from reference collections is an integral component of zooarchaeological standards for quality control (Driver 1992, 2011).

The artifiction replications described here improve on existing 3D models by offering a visual and physical representation of the size and shape of individual bones from these extinct species, which will increase their identification potential. The Virtual Curation Laboratory at Virginia Commonwealth University has explored the issue of identification using 3D digital models versus printed replicas in informal discussions with established scholars and observed that virtual 3D models are challenging for some researchers to use, particularly among zooarchaeologists who utilize conventional comparative collections (Lyman 2010). This situation occurs, in part, because the scale of digital models is based on the size of the screen upon which they are viewed, making identifications by direct comparison difficult. Artifictions, however, can be scaled accurately and physically placed alongside actual skeletal elements to enable more direct visual comparison and identification of specimens, comparable to the use of a reference specimen from a comparative skeletal collection. Additionally, the 3D scanned models can be used for species identification based on selected point-to-point morphometric measurements. 


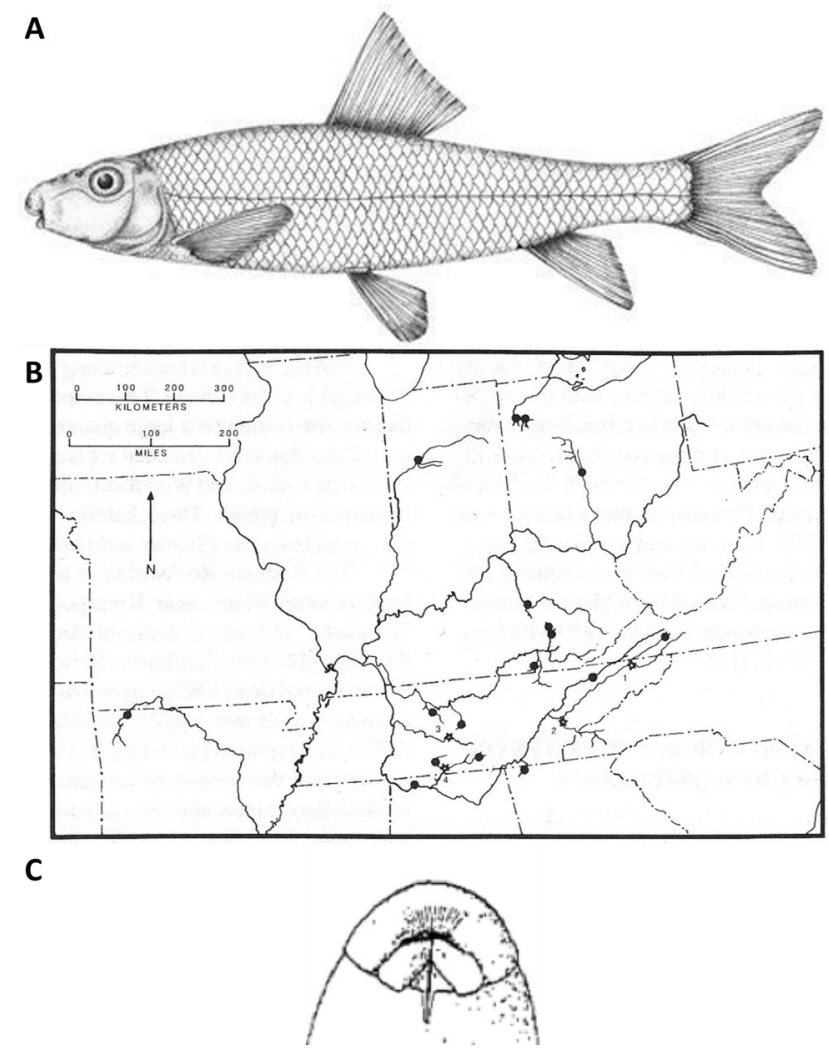

Figure 2. A) Moxostoma lacerum (reproduced with permission from the Smithsonian National Museum of Natural History, illustration \#P14570). B) Antero-ventral view of harelip sucker showing deep grooved divided lower lip. C) Distribution of Moxostoma lacerum showing historic collection sites (dots) and archaeological sites (stars): 1. Eastman Rockshelter (40SL34); 2. Martin Farm site (40MR20); 3. Hays site (40ML139); 4. Bailey site (40GL26). (Figures $2 \mathrm{~b}$ and $2 \mathrm{c}$ are from Manzano and Dickinson 1991 and were reproduced with permission from the Illinois State Museum).

Ultimately, this method seeks to promote greater ability of zooarchaeologists to identify passenger pigeon and harelip sucker remains to help address 1) how frequent these two extinct species are in prehistoric and historic archaeological assemblages across their recorded habitat ranges, and 2) the species' prehistoric population sizes and ranges compared to that recorded for them during the historic period.

\section{Materials}

Ectopistes migratorius (Passenger Pigeon)

There appear to be only 16 complete skeletons and one partial skeleton of passenger pigeon in museum collections, whereas there are 1,532 known skins and mounts of this species in collections throughout the world, based on reports by Hahn (1963), Greenberg (2014:214) and Schorger (1955:238-239). In his publication on the osteology of the passenger pigeon, Shufeldt (1914:358-362) shows one of two photographs of a nearly complete passenger pigeon skeleton documented in the literature (Figure 1c) along with the descriptions and measurements of several elements. Schorger (1955: Figure 10) shows a different photograph of the same skeleton from the Smithsonian Institution. Other reports on passenger pigeon bones offer a few photographs, drawings, and measurements of key elements from paleontological contexts (Howard 1937) or from skeletons collected before extinction with some comparison to elements from other Columbidae (Dodson 1950:39-40; Pitelka and Bryant 1942; Shufeldt 1901).

Gilbert et al. (1981) is the only reference we obtained in the zooarchaeological literature that offers selected drawings and key measurements of passenger pigeon bones from collections at the University of Missouri, American Museum of Natural History, University of Kansas, Royal Ontario Museum, and Smithsonian Institution. Consequently, there are few literature sources and a limited amount of study reference specimens to help researchers identify passenger pigeon bones. Researchers are compelled to the use difficult-to-obtain archaeological or paleontological specimens for their identifications. This void in reference specimens makes the production and employment of passenger pigeon 'artifictions' a promising approach to use in the identification of remains of this species within archaeological or paleontological faunal assemblages.

To create passenger pigeon artifictions, the authors obtained post-cranial elements (Table 1) from an archaeological site in the collections of the Virginia Museum of Natural History. The Graham-White site, a Native American village located in Roanoke County, Virginia, had a few pit features where there were significant numbers of passenger pigeon bones (Elizabeth Moore, personal communication, 2014). We also selected two skulls, a sternum, and pelvic bones of passenger pigeon, collected during the $19^{\text {th }}$ century (according to the catalog) for this study and scanned them in the Division of Birds at the Smithsonian National Museum of Natural History.

\section{Moxostoma lacerum (Harelip Sucker)}

The harelip sucker, Moxostoma lacerum, renamed from Lagocbila lacera through research by Smith (1992) is the 
first recorded freshwater fish to have become extinct in the United States in the early 20th century (Jenkins 1980:407). The common name of harelip as noted by Jordan and Evermann (1896:106) is based on the divided lower lip and deeply grooved, nonprotrusible, and hooded upper lip of the fish (Figure 2b). Harelip suckers preferred medium to large warm streams of moderate gradient, relatively low turbidity and silt levels, commonly inhabiting long pools and slower runs (Jenkins 1980:407). Evidence suggests that this species visually foraged for their food rather than tactilely as do most other Moxostoma (Miller and Evens 1965:476). Its extinction likely stemmed from $19^{\text {th }}$ century land clearing and agricultural practices that increased stream siltation and turbidity, preventing the species from effectively detecting food.

Although this species was once relatively common, curated skeletal remains of this species are extremely rare. Sabaj et al. (1997: 254) record that Jenkins (1994) lists only 33 extant nonfossil specimens mostly preserved in fluid and curated at ten museums and collected from no more than 20 capture locations for specimens collected from 1859 to 1893 (Figure 2c). As a result, skeletal specimens are extremely limited in number. Manzano and Dickinson (1991:84) used one dry, partially disarticulated specimen that was then the only known comparative skeleton at the Smithsonian National Museum of Natural History (USNM \#26736). More recently, Fink and Humphries (2010:5) have used high resolution x-ray computed tomography (HRXCT) to study another disarticulated skeleton (USNM \#36189) at the Smithsonian Institution, focusing on the species' unique oral skeletal morphology.

The harelip sucker was first reported archaeologically in 1985 from the prehistoric Martin Farm site (40MR20) located in Monroe County, Tennessee (Bogan and Bogan 1985). Manzano (1986) with assistance from William C. Dickinson, who was familiar with the fish skeletons at the Smithsonian Institution, reported 113 harelip sucker remains from the Eastman Rockshelter (40SL34) located in Sullivan County, Tennessee. Later, Manzano and Dickinson (1991) described the osteological characteristics of 13 harelip sucker cranial elements from the shelter, of which five (Table 1, Figure 3a-n) were 3D scanned to create the artifictions for this paper.

\section{Methods}

For this analysis, Bernard K. Means and Virginia Commonwealth University undergraduate assistants at

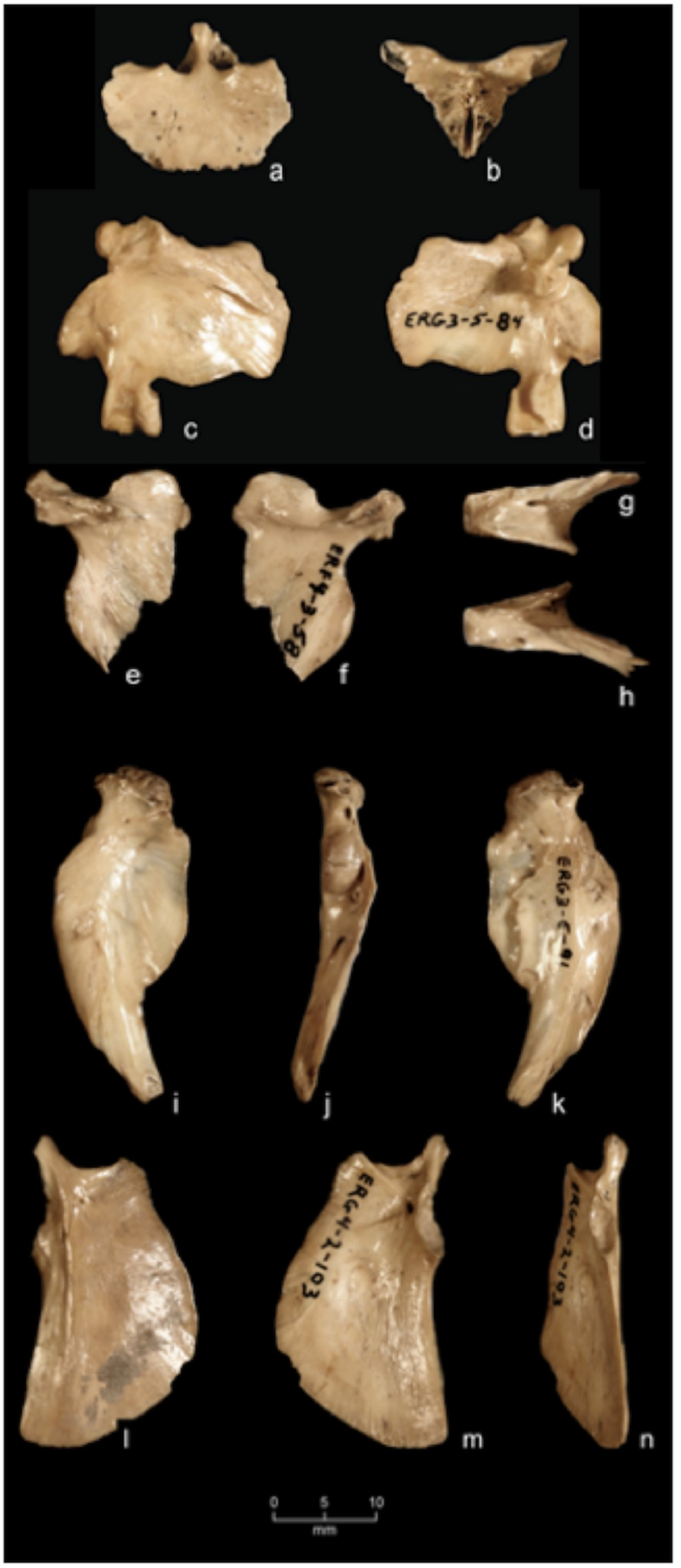

Figure 3. Five Moxostoma lacerum elements recovered from the Eastman Rockshelter used for this study: supraethmoid (catalogue \# ERB3-2-18, a. dorsal, b. anterior), right maxillary (catalogue \# ERG3-5-84, c. lateral, d. mesial), left dentary (catalogue \# ER4-328, e. lateral, f. mesial; catalogue \# ERC4-6-31, g. dorsal, h. ventral); right hyomandibular (catalogue \# ERG3-6-91, i. lateral, j. anterior, k. mesial), left operculum (catalogue \# ERG4-2-103, I. lateral, m. mesial; catalogue \# ERF2-9-49, n. anterior fragment). 
Table 1. Elements 3D Scanned to Create Artifictions.

\begin{tabular}{|c|c|c|c|}
\hline Taxon & Common name & Element & Side \\
\hline \multirow[t]{8}{*}{ Ectopistes migratorius } & Passenger Pigeon & Skull & \\
\hline & & Sternum & \\
\hline & & Coracoid & Left \\
\hline & & Radius & Right \\
\hline & & Carpometacarpus & Right \\
\hline & & Pelvis & Left \\
\hline & & Femur & Right \\
\hline & & Tarsometatarsus & Right \\
\hline \multirow[t]{5}{*}{ Moxostoma lacerum } & Harelip Sucker & Supraethmoid & \\
\hline & & Maxillary & Right \\
\hline & & Dentary & Left \\
\hline & & Hyomandibular & Right \\
\hline & & Operculum & Left \\
\hline
\end{tabular}

the Virtual Curation Laboratory used a NextEngine Desktop 3D scanner to create 3D digital topological models of eight passenger pigeon and five harelip sucker skeletal elements (Table 1) (Means et al. 2013a, b; Zechini 2014a, b, c, d). The scanned digital models were edited as required using the ScanStudio program. This editing removes extraneous digital data that is recorded during scanning, such as the platform used to support each element as it is scanned, as well as digital noise that is generated during the scanning process. Additionally, most elements require two scans to ensure complete recording of the element and these need to be digitally merged (Means et al. 2013a). After editing, digital files of the 3D bone models were used to create the passenger pigeon and harelip sucker skeletal artifictions with a MakerBot Replicator 3D printer (Figure 4a) with the surfaces of some painted with acrylics to give them a light tan bone appearance (Figure 4b).

\section{Discussion}

Obvious problems with artifictions became immediately apparent during this project and relate to the recent development of 3D printing and its new application in zooarchaeology (Weber and Malone 2011). First, artifictions do not have the feel, weight, color, or detail of actual bone. Second, some artifictions are not yet reproducible with current homebased 3D printers because certain elements, particularly thin ones such as fish bone, while able to be scanned, are difficult to generate into artifictions due to the limited resolution power of the noncommercial 3D printer used in this study ${ }^{3}$ - and the challenge of removing supporting material (e.g., the base) from thin replicas. Third, and related to the second point, the 3D printer made it difficult to replicate very small elements, such as individual passenger pigeon vertebrae.

Nevertheless, there are several positive outcomes that strongly support the application of artifictions in zooarchaeology, paleontology, and conservation biology (see Means 2015b). First, this is the only noncommercial approach that will make available physical representations of skeletal elements from extinct species for quick distribution to a large number of researchers. Second, producing artifictions results in a digital model that can be virtually measured for additional comparative purposes and that will always produce the same 3D replica, if printed out in the same manner on the same model of printer. Third, possible damage to rare specimens is minimized with use of artifictions especially if the actual specimens are too fragile to endure the process of molding and casting. Fourth, improvements in techniques, 3D scanning programs, and printing machines are increasing rapidly and promise to reduce the problems noted above. Thus, the many competitors entering the market with new 3D scanners and printers on an almost weekly basis—especially for 3D printersrequires one to regularly keep abreast of the technological advancements through blogs, websites, and magazines (for example, see Anderson 2014; Gizmodo 2015). Especially promising are efforts to make more inexpensive versions of Stereo-Lithographic Apparatus (SLA) or Selective Laser Sintering (SLS) printers suitable for consumer use. These types of printers offer the ability to print artifictions with 


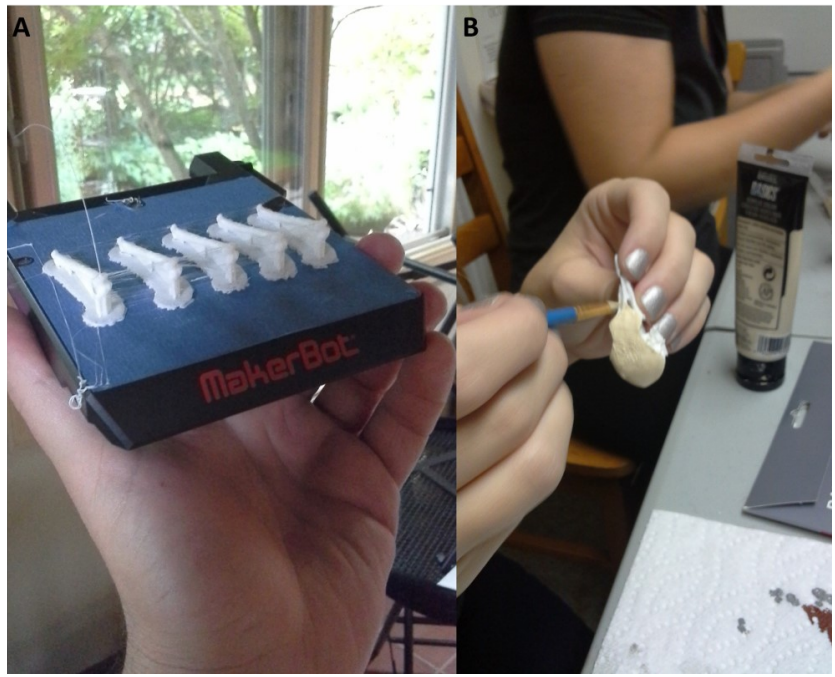

Figure 4. A) Five newly created 3D printed passenger pigeon femurs. B) Digital zooarchaeologist Rebecca Bowman paints a printed passenger pigeon cranium.

greater resolution and fidelity than is possible with thermoplastic extrusion printers that are currently being used, such as the MakerBots used to create artifictions for this study (see Barnatt 2013 for details on these printing technologies).

Additional research such as Fink and Humphries' (2010) use of high resolution x-ray computed tomography (HRXCT) to examine the harelip sucker skeletal morphology of bones from the face, jaws, and pharynx to reconstruct a virtual skeleton shows great promise for generating artifictions. Their work digitally disarticulated individual skeletal elements for 2D virtual examination but lacked a scale for comparison to actual specimens. Future approaches using HRXCT models in 3D digital form with a scale can generate artifictions from mounted passenger pigeon and fluid-preserved harelip sucker specimens. Such a dual approach will enable more skeletons of these animals to be examined and greater documentation of intraspecific morphological variability. The documentation of these extinct species in archaeological contexts will enhance the estimation of their habitat ranges and how their prehistoric populations compare to the population sizes and ranges recorded for these species during the historic period.

These topics are addressed for passenger pigeon remains present at prehistoric archaeological sites in the northeastern (Neumann 1985) and southeastern Jackson 2005) United States. Both reports model the archaeological presence of passenger pigeons within an ecological framework, consider changes in pigeon and human populations, and explore how changes in prehistoric and historic human use such as large-scale land clearance and agriculture possibly influenced passenger pigeon population size and distribution across the country.

Given the under-reporting of harelip sucker bones from archaeological contexts, it remains to be seen if an evolving ecological system model may also help explain the yet only marginally documented frequency of this species from prehistoric and historic sites within the United States. The remains of the harelip sucker should be found at archaeological sites along its preferred habitats mentioned above and its archaeological presence overall would indicate a clear streams near sites. Jenkins (1970:537) wrote, however, that "even in prehistoric times [harelip sucker] populations may have been in precarious balance due to a dependency upon the clearest of waters," which varied over time and across space with some coincident to prehistoric human land-use activities (Peacock et al. 2005). Humans during the historic period heavily impacted such stream water conditions that likely caused the extinction of the harelip sucker.

Consequently, additional observations of harelip sucker remains from archaeological sites represent opportunities to study the habitat range of a little known, extinct fish species. Manzano and Dickinson (1991:87) previously urged researchers to examine archaeological fish assemblages for harelip sucker remains using the element illustrations in their article but were unable to provide ready access to comparative specimens. In contrast, this report makes the same request with additional illustrations (Figure 3a-n, see Manzano and Dickinson 1991) as well as the new approach of providing artifictions to help identify remains of this species in archaeological assemblages. Efforts are currently underway to make these digital models available for download in the Virtual Curation Laboratory section of the Center for Regional Heritage Research digital archive at Stephen F. Austin State University by August 2016 (VCL 3D Collections 2015). Like other 3D scans of zooarchaeological collections, artifictions will offer researchers an opportunity to determine if passenger pigeon and harelip sucker bones are in recovered faunal assemblages, increasing our knowledge about the distribution of these species. 


\section{Acknowledgments}

We extend our thanks to Dr. Jay Franklin (East Tennessee State University) for the loan of the harelip sucker elements, Dr. Elizabeth Moore (Virginia Museum of Natural History) and Brian Schmidt (Division of Birds, Smithsonian National Museum of Natural History) for access to the passenger pigeon specimens. Thanks also are extended to William $\mathrm{H}$. Wilkerson (University of Kentucky) for his expertise in photographing the harelip sucker elements. Likewise, we extend our thanks to the many undergraduate VCU students working in the VCL for their continued efforts in this project.

\section{Declarations}

Permissions: Figures 1A and 2A were reproduced with permission from the Smithsonian National Museum of Natural History; Figure 1B, was reproduced with permission from the University of Oklahoma Press, Figure 1C, was reproduced with permission from The Auk; Figures 2B and 2C were reproduced with permission from the Illinois State Museum.

Sources of Funding: US Department of Defense Legacy Program, Number 11-334 to Dr. Bernard K. Means, School of World Studies at Virginia Commonwealth University.

Conflicts of Interest: None.

\section{References Cited}

Ahmed, N., M. Carter and N. Ferris. 2014. Sustainable Archaeology Through Progressive Assembly 3D Digitization. World Archaeology 46:137-154.

Anderson, S. 2014. Make: Magazine Shootout Names Top 10 3D Printers. Available at: http://3dprint.com/23676/make-magazine-top-10printers. Accessed on 11 May 2015.

Barnatt, C. 2013. 3D Printing: The Next Industrial Revolution. CreateSpace Independent Publishing Platform.

Betts, M. W., H. D. G. Maschner, C. D. Schou, R. Schlader, J. Holmes, N. Clement and M. Smuin. 2011. Virtual Zooarchaeology: Building a Webbased Reference Collection of Northern Vertebrates for Archaeofaunal Research and Education. Journal of Archaeological Science 38:755-762.

Bogan, A. E. and C. M. Bogan. 1985. Faunal Remains. In Archaeological Contexts and Assemblages at Martin Farm, edited by G. F. Schroedl, R. P. S. Davis, Jr. and C. C. Boyd, Jr., pp. 369-410. University of
Tennessee, Department of Anthropology, Report of Investigation No. 39.

Chapman, H., E. Baldwin, H. Moulden and M. Lobb. 2013. More than Just a Sum of the Points: Re-

Thinking the Value of Laser Scanning Data. In $V$ isual Heritage in the Digital Age, edited by E. Ch'ng, V. Gaffney and H. Chapman, pp. 15-31. SpringerVerlag, London.

Dodson, E. O. 1950. An Available Passenger Pigeon Skeleton. Condor 52:39-40.

Driver, J. C. 1992. Identification, Classification, and Zooarchaeology. Circaea 9:35-47.

Driver, J. C. 2011. Identification, Classification, and Zooarchaeology (featured reprint and invited comments). Ethnobiology Letters 2:19-39.

Fink, W. L. and J. H. Humphries. 2010. Morphological Description of the Extinct North American Sucker Moxostoma lacerum (Ostariophysi, Catostomidae), Based on High-Resolution X-Ray Computed Tomography. Copeia 1:5-13.

Gilbert, B. M., L. D. Marin and H. G. Savage. 1981. Avian Osteology. Modern Printing Company, Laramie, MO.

Gizmodo. 2015. 3D Scanning. Available at: http:// gizmodo.com/tag/3d-scanning. Accessed on 11 May 2015.

Greenberg, J. 2014. A Feathered River Across the Sky: The Passenger Pigeon's Flight to Extinction. Bloomsbury, New York, NY.

Hahn, P. 1963. Where is that Vanished Bird? University of Toronto Press, Toronto.

Heerlien, M., J. van Leusen, S. Schnörr and K. van Hulsen. 2013. The Natural History Production Line: An Industrial Approach to the Digitization of Scientific Collections. Paper presented at the Proceeding of the 2013 Digital Heritage International Congress (DigitalHeritage), Marseille.

Howard, H. 1937.A Pleistocene Record of the Passenger Pigeon in California. Condor 39:12-14.

Jackson, H. E. 2005. Darkening the Sun in Their Flight: A Zooarchaeological Accounting of Passenger Pigeons in the Prehistoric Southeast. In Engaged Anthropology, edited by M. Hegmon and B. S. Eiselt, pp. 174-199. University of Michigan Museum, Ann Arbor, MI. 
Jenkins, R. E. 1970. Systematic Studies of the Catostomid Fish Tribe Moxostomatini. Unpublished Dissertation, Department of Ecology and Evolutionary Biology, Cornell University, Ithaca, NY.

Jenkins, R. E. 1980. Lagochila lacera (Harelip Sucker). In Atlas of North American Freshwater Fishes, edited by D. S. Lee, C. R. Gilbert, C. H. Hocult, R. E. Jenkins, D. E. McAllister and J. R. Stauffer, Jr., p. 407, North Carolina State Museum of Natural History, Raleigh, NC.

Jenkins, R. E. 1994. Harelip Sucker Moxostoma lacerum (Jordan and Brayton), In Freshwater Fishes of Virginia, edited by R. E. Jenkins and N. M. Brayton, pp. 519523. American Fisheries Society, Bethesda, MD.

Jordan, D. S. and A. W. Brayton. 1877. On Lagochila, a New Genus of Catostomid Fishes. Proceedings of the Academy of Natural Sciences of Philadelphia 29:280-283.

Jordan, D. S. and B. W. Evermann. 1896. The Fishes of North and Middle America: A Descriptive Catalogue of the Species of Fish-like Vertebrates Found in the Waters of North America, North of the Isthmus of Panama. Bulletin of the United States Natural Museum 47:1-1240.

Klippel, W. E. and P. W. Parmalee. 1982. Diachronic Variation in Insectivores from Cheek Bend Cave and Environmental Change in the Midsouth. Paleobiology 8:447-458.

Linnaeus, C. 1766. Systema Naturae. $12^{\text {th }}$ edition. Impensis Laurenti Salvii, Holmaie, Stockholm.

Lyman, R. L. 1996. Applied Zooarchaeology: The Relevance of Faunal Analysis to Wildlife Management. World Archaeology 28:110-125.

Lyman, R. L. 2010. Paleozoology's Dependence on Natural History Collections. Journal of Ethnobiology 30:126-136.

Lyman, R. L. 2012. Applied Zooarchaeology: History, Value, and Use. In Conservation Biology and Applied Zooarchaeology, edited by S. Wolverton and R. L. Lyman, pp. 208-232. University of Arizona Press, Tucson, AZ.

Manzano, B. L. 1986. Faunal Resources, Butchering Patterns, and Seasonality at the Eastman Rockshelter (40SL34): An Interpretation of Function.
Unpublished Master's Thesis, Department of Anthropology, University of Tennessee, Knoxville.

Manzano, B. L., and W. C. Dickenson. 1991. Archaeological Occurrences of the Extinct Harelip Sucker, Lagochila lacera Jordan and Brayton (Pisces:

Catostomidae). In Beamers, Bobwhites, and Blue-Points: Tributes to the Career of Paul W. Parmalee, edited by J. R. Purdue, W. E. Klippel and B. W. Styles, pp. 8792. Illinois State Museum Scientific Papers, Vol. 23, Springfield, IL.

McCuistion, A. 2013. Promoting the Past: The Educational Applications of 3D Scanning Technology in Archaeology. Journal of Middle Atlantic Archaeology 29:35-42.

McKechnie, I. and S. W. Kansa. 2011. Transformations in Digital Communication and Collaboration, Recent Perspectives from Zooarchaeology. The SAA Archaeological Record 11:15-18.

Means, B. K. 2015a. If They Can Build It Will They Come? Using Artifictions and Ecofictions to Teach the Past. Paper presented at the 48th Annual Conference of the Society for Historical and Underwater Archaeology, Seattle, WA.

Means, B. K. 2015b. Copycats: Casting and Molding versus 3D Scanning and Printing. The Virtual Curation Laboratory. Available at https:// vcuarchaeology3d.wordpress.com//?s=copycats. Accessed on 1 August 2015.

Means, B. K. 2014. Virtual Curation and Virtual Collaboration. In Blogging Archaeology, edited by D. Rocks-Macqueen and C. Webster, pp. 121-144. Landward Research, Ltd. in Association with Succinct Research and DIGTECH LLC.

Means, B. K., C. Bowles, A. McCuistion and C. King. 2013a. Virtual Artifact Curation: Three-Dimensional Digital Data Collection for Artifact Analysis and Interpretation. Prepared for the Department of Defense Legacy Resource Management Program, Legacy Project \#11-334. Prepared by the Virtual Curation Laboratory, Virginia Commonwealth University, Richmond, VA.

Means, B. K., A. McCuistion and C. Bowles. 2013b. Virtual Artifact Curation of the Historic Past and the Next Engine Desktop 3D Scanner. Technical Briefs in Historical Archaeology 7:1-12. Available at: http://www.sha.org/assets/documents/ 
Technical_briefs_articles/VirtualAritfacts.pdf. Accessed on 1 August 2015.

Miller, R. J. and H. E. Evans. 1965. External Morphology of the Brain and Lips in Catostomid Fishes. Copeia 4:467-487.

Neumann, T. 1985. Human-Wildlife Competition and the Passenger Pigeon: Population Growth from System Destabilization. Human Ecology 13:389-410.

Peacock, E., W. R. Haag and M. L. Warren. 2005. Prehistoric Decline in Freshwater Mussels Coincident with the Advent of Maize Agriculture. Conservation Biology 19:547-551.

Pitelka, F. A. and M. D. Bryan. 1942. Available Skeletons of the Passenger Pigeon. Condor 44:74-75.

Richter, A., V. Petrovic, D. Vanoni, S. M. Parish, F. Kuester and T. E. Levy. 2013. Digital Archaeological Landscapes and Replicated Artifacts: Questions of Analytical and Phenomenological Authenticity and Ethical Policies in CyberArchaeology. Paper Presented at the Proceeding of the 2013 Digital Heritage International Congress (DigitalHeritage), Marseille, France.

Sabaj, M. H., K. S. Cummings and L. M. Page. 1997. Annotated Catalog of Type Specimens in the Illinois Natural History Survey Fish Collection. Illinois Natural History Survey Bulletin 35:253-300.

Schorger, A. W. 1955. The Passenger Pigeon: It's Natural History and Extinction. University of Wisconsin, Madison, WI.

Scott, E. M. 2008. Who Ate What? Archaeological Food Remains and Cultural Diversity. In Case Studies in Environmental Archaeology, edited by E. Reitz, C. M. Scarry and S. J. Scudder, pp. 357-374. Springer, NY.

Shufeldt, R. W. 1901. On the Osteology of the Pigeons (Columbae). Journal of Morphology 18:487512.

Shufeldt, R. W. 1914. Osteology of the Passenger Pigeon (Ectopistes migratorius). Auk 31:358-362.

Sims, M. E., B. W. Baker and R. M. Hoesch. 2011. Tusk or Bone? An Example of Ivory Substitute in the Wildlife Trade. Ethnobiology Letters 2:40-44.

Smith, G. R. 1992. Phylogeny and Biogeography of the Catostomidae, Freshwater Fishes of North America and Asia. In Systematics, Historical Ecology, and North American Freshwater Fishes, edited by R. L.
Mayden, pp. 778-826. Stanford University Press, Stanford, CA.

Virtual Curation Laboratory. 2015. VCL 3D Collections. Available at http://crhrarchive.sfasu.edu/ handle/123456789/53. Accessed on 11 May 2015.

Weber, J. A. and E. Malone. 2011. Exporting Virtual Material Culture: Cheap and Easy Methods to Preserve and Share Data. The SAA Archaeological Record 11:15-18.

Wolverton, S. and R. L. Lyman, eds. 2012. Conservation Biology and Applied Zooarchaeology. University of Arizona Press, Tucson, AZ.

Zechini, M. 2014a. Zooarchaeology in the $21^{\text {st }}$ Century. Quarterly Bulletin of the Archeological Society of Virginia 69:29-36.

Zechini, M. 2014b. Rocky Raccoon: The Application of 3D Technology to Zooarchaeology. Pennsylvania Archaeologist 84:19-22.

Zechini, M. 2014c. Digital Zooarchaeology: Faunal Analysis in the 21 st Century. Unpublished Undergraduate Honors Thesis in Anthropology, School of World Studies, Virginia Commonwealth University, Richmond, VA.

Zechini, M. 2014d. Digital Zooarchaeology: Using 3D Technology on Archaeofaunal Collections. Quarterly Bulletin of the Archeological Society of V irginia 69:215228.

\section{Notes}

1"Artifictions" is a term coined by the Virtual Curation Laboratory to refer to printed replicas of archaeological remains (Means 2014, 2015; Means et al. 2013a, b; Zechini 2014a, b, c, d).

2Seminal works by Schorger (1955) and Greenberg (2014) offer researchers the life history of this important bird species.

${ }^{3}$ The maximum resolution is $0.1 \mathrm{~mm}$ for the MakerBot Replicator 2 (https://store.makerbot.com/ replicator2.html).

\section{Biosketches}

Bruce L. Manzano is Project Manager at the Program for Archaeological Research at the University of Kentucky. 
Bernard K. Means is Director of the Virtual Curation Laboratory and Professor at the School of World Studies at Virginia Commonwealth University.

Christopher T. Begley is Associate Professor of Anthropology and Director of the Exploration Foundation at Transylvania University.
Mariana Zechini is a graduate student at the University of West Florida and completed her B.A. from Virginia Commonwealth University focusing on 3D technology in zooarchaeology. 